\title{
PENGARUH KETERSEDIAAN FASILITAS BELAJAR SAAT PEMBELAJARAN DARING TERHADAP PRESTASI BELAJAR PESERTA DIDIK SMK KARSA MULYA PALANGKA RAYA PADA TAHUN PELAJARAN 2021/2022
}

\author{
Maria Tumaris Anggraeny Marpaung ${ }^{1}$ Nani Setiawati ${ }^{2}$ Ima Pinensi Br Tarigan ${ }^{3}$ \\ ${ }^{1}$ Fakultas IImu Pendidikan, Universitas Palangka Raya
}

\begin{abstract}
ABSTRAK
Pandemi Covid-19 sudah merubah tatanan hidup hampir keseluruhan penduduk yang ada di dunia dan di semua aspek kehidupan yang mempengaruhi kehidupan orang banyak termasuk Pendidikan. Akibat dari pandemik Covid-19 yang melanda sehingga pembelajaran tidak berjalan optimal karena peserta didik harus mengikuti di rumah. Pembelajaran yang dilakukan di rumah, kesusahan yang sangat besar yang dihadapkan untuk guru merupakan dikala melaksanakan tata cara belajar di rumah serta kelengkapan fasilitas prasarana ataupun fasilitas belajar peserta didik di rumah. yang turut memberikan pengaruh terhadap prestasi belajar peserta didik. Penelitian ini dilakukan untuk mengetahui pengaruh ketersediaan fasilitas belajar saat pembelajaran daring terhadap prestasi belajar peserta didik SMK Karsa Mulya Palangka Raya pada tahun pelajaran 2021/2022.

Jenis penelitian ini adalah penelitian deskriptif dengan pendekatan kuantitatif Subjek dalam penelitian ini adalah peserta didik Kelas $X$ Multimedia A dengan jumlah 36 orang dan peserta didik kelas Kelas $\mathrm{X}$ Multimedia B dengan jumlah 36 orang. Penelitian ini menggunakan alat pengumpulan data berupa angket dan dokumentasi. Teknik analisis data yang digunakan adalah uji regresi.

Berdasarkan data yang diperoleh dari hasil analisis yang dilakukan maka dapat ditarik kesimpulan bahwa terdapat pengaruh yang signifikan antara ketersediaan fasilitas belajar saat pembelajaran daring terhadap prestasi belajar peserta didik SMK Karsa Mulya Palangka Raya pada tahun pelajaran 2021/2022. Hal tersebut dapat ditunjukkan dengan nilai thitung sebesar 3,638, koefisien regresi (b) sebesar 0,294, dan nilai signifikansi sebesar 0,001 karena koefisien regresi mempunyai nilai positif dan nilai signifikan $(p)<0,05$ maka dapat disimpulkan bahwa semakin lengkap ketersediaan fasilitas belajar saat pembelajaran daring maka semakin tinggi prestasi belajar peserta didik SMK Karsa Mulya Palangka Raya pada tahun pelajaran 2021/2022.
\end{abstract}

Kata Kunci: Fasilitas Belajar, Prestasi Belajar

\section{PENDAHULUAN}

Pandemi Covid-19 sudah merubah tatanan hidup hampir keseluruhan penduduk yang ada di dunia dan di semua aspek kehidupan yang mempengaruhi kehidupan orang banyak termasuk pendidikan. Penyampaian pendidikan, dalam kegiatan formal maupun informal dialihkan pada tata cara pembelajaran online guru sebagai pengajar dan peserta didik yang menerima pembelajaran dituntut untuk paham dan bisa menjalankan teknologi. Masalah menjadi muncul sejalan dengan peralihan metode pembelajaran secara offline/tatap muka menjadi pembelajaran online/melalui jaringan internet. Ketidaksiapan para pendidik serta peserta didik dan sarana sekolah dalam menghadapi situasi yang terjadi membuat seluruh pihak agar melakukan refleksi serta memperbaiki diri. 
Akibat dari pandemik Covid-19 yang melanda sehingga pembelajaran tidak berjalan optimal karena peserta didik harus mengikuti di rumah. Pembelajaran yang dilakukan di rumah, kesusahan yang sangat besar yang dihadapkan untuk guru merupakan dikala melaksanakan tata cara belajar di rumah serta kelengkapan fasilitas prasarana ataupun fasilitas belajar peserta didik di rumah.

Fasilitas belajar yang diartikan dalam hal ini merupakan fasilitas yang menunjang kegiatan belajar mengajar yang tidak dicoba di sekolah, namun di rumah disebabkan sesuatu hal seperti saat ini masih dalam masa pandemi. Fasilitas-fasilitas belajar yang sekarang ini digunakan pada masa pandemi Covid 19, yaitu handphone, laptop, wifi/kuota internet serta aplikasi contohnya WhatsApp, Zoom, dan Google Classroom.

SMK Karsa Mulya Palangka Raya merupakan salah satu sekolah ada di Kota Palangka Raya. Terkait dengan adanya wabah virus corona ini tentunya sekolah mengikuti arahan dari pemerintah untuk meniadakan semua aktivitas belajar mengajar di sekolah kemudian digantikan melalui pembelajaran di ruang dengan menggunakan media online. Hal ini memberikan dampak dan perubahan yang sangat besar yang awalnya sebelum ada pandemi Covid-19 pembelajaran dilakukan secara langsung tiba-tiba harus dilakukan secara daring. Pembelajaran yang disampaikan secara daring, yaitu penyampaian materi, pemberian dan pengumpulan tugas, dan pemberian tes atau ujian.

Berdasarkan hasil observasi di SMK Karsa Mulya Palangka Raya selama pembelajaran online dilakukan, tidak semua peserta didik mampu mengikuti pembelajaran daring dengan baik. Hal tersebut disebabkan oleh penyediaan fasilitas belajar dari orang tua yang kurang memadai dan peserta didik pun belum terbiasa melakukan pembelajaran secara online, sehingga pembelajaran bermakna terasa sulit diupayakan. Ketersediaan fasilitas belajar pada saat pembelajar online yang tidak memadai menyebabkan nilai peserta didik tersebut tidak mencapai KKM.

Berdasarkan latar belakang tersebut, maka dirasa perlu untuk melakukan penelitian untuk melihat sejauh mana persepsi peserta didik tentang pengaruh ketersediaan fasilitas belajar saat pembelajaran daring terhadap prestasi belajar peserta didik SMK Karsa Mulya Palangka Raya pada tahun pelajaran 2021/2022.

\section{KAJIAN PUSTAKA}

\section{Ketersediaan Fasilitas Belajar}

Ketersediaan adalah kesiapan suatu sarana (tenaga, barang, modal, anggaran) ntuk dapat digunakan atau dioperasikan dalam waktu yang telah ditentukan (Wiktionary, 2017). Sedangan menurut Tim KBBI (2016) bahwa ketersediaan adalah keadaan tersedia; hal tersedia.

Djamarah (2012) mengemukakan bahwa fasilitas belajar merupakan kelengkapan belajar yang harus dimiliki oleh sekolah. Menurut Mulyasa (2013) bahwa yang dimaksud dengan fasilitas belajar atau sarana pendidikan adalah peralatan dan perlengkapan yang secara langsung dipergunakan dan menunjang proses pendidikan, khususnya proses belajar mengajar, seperti gedung, ruang kelas, meja kursi, serta alat-alat dan media pengajaran. Adapun yang dimaksud dengan prasarana pendidikan adalah fasilitas yang secara tidak langsung menunjang jalannya proses pendidikan atau pengajaran, seperti halaman, kebun, taman sekolah, jalan menuju sekolah, tetapi jika dimanfaatkan secara langsung untuk proses belajar mengajar, seperti taman sekolah untuk pengajaran biologi, halaman sekolah sebagai sekaligus lapangan olahraga, komponen tersebut merupakan sarana pendidikan.

Arikunto (2014:273) mengemukakan bahwa yang dimaksud dengan "fasilitas belajar adalah semua fasilitas yang diperlukan dalam proses belajar mengajar yang bergerak maupun yang tidak bergerak agar pencapaian tujuan berjalan lancar, teratur, efektif dan efisien". 


\section{Prestasi Belajar}

Anitah (2014: 4) merumuskan "prestasi belajar merupakan perubahan perilaku yang diperoleh pembelajar setelah mengalami aktivitas belajar". "Prestasi belajar juga merupakan kemampuan yang diperoleh peserta didik setelah melalui kegiatan belajar" (Nashar, 2012: 77). Keller (Nashar, 2012), "prestasi belajar adalah terjadinya perubahan dari hasil masukan pribadi berupa motivasi dan harapan untuk berhasil dan masukan dari lingkungan berupa rancangan dan pengelolaan motivasional tidak berpengaruh terhadap besarnya usaha yang dicurahkan oleh peserta didik untuk mencapai tujuan belajar".

Menurut Dalyono (2012) faktor eksternal (yang berasal dari luar diri orang belajar) antara lain: yaitu

1) Keluarga. Faktor orang tua sangat besar pengaruhnya terhadap keberhasilan anak dalam belajar, misalnya tinggi rendahnya pendidikan, besar kecilnya penghasilan dan perhatian.

2) Sekolah. Keadaan sekolah tempat belajar turut mempengaruhi tingkat keberhasilan anak. Kualitas guru, metode mengajarnya, kesesuaian kurikulum dengan kemampuan anak, keadaan fasilitas atau perlengkapan di sekolah dan sebagainya, semua ini mempengaruhi keberhasilan belajar.

3) Masyarakat. Keadaan masyarakat juga menentukan prestasi belajar. Bila sekitar tempat tinggal keadaan masyarakatnya terdiri dari orang-orang yang berpendidikan, terutama anak-anaknya, rata-rata bersekolah tinggi dan moralnya baik, hal ini akan mendorong anak giat belajar.

4) Lingkungan sekitar. Keadaan lingkungan tempat tinggal, juga sangat mempengaruhi prestasi belajar. Keadaan lingkungan, bangunan rumah, suasana sekitar, keadaan lalu lintas dan sebagainya semua ini akan mempengaruhi kegairahan belajar

\section{METODE}

Jenis penelitian ini adalah penelitian deskriptif dengan pendekatan kuantitatif Subjek dalam penelitian ini adalah peserta didik Kelas X Multimedia A dengan jumlah 36 orang dan peserta didik kelas Kelas X Multimedia B dengan jumlah 36 orang. Penelitian ini menggunakan alat pengumpulan data berupa angket dan dokumentasi. Teknik analisis data yang digunakan adalah uji regresi.

\section{HASIL DAN PEMBAHASAN}

\section{A. Uji Prayarat Analisis}

\section{Uji Normalitas}

Uji normalitas digunakan untuk mengetahui apakah data yang bersangkutan berdistribusi normal atau tidak. Penelitian ini menggunakan rumus Kolmogorov-Smirnov yang dihitung menggunakan bantuan aplikasi IBM SPSS Statistik v.25. Hasil analisis dapat dilihat pada tabel berikut.

\section{Tabel Rangkuman Hasil Uji Normalitas Data}

\begin{tabular}{llcc}
\hline No & \multicolumn{1}{c}{ Variabel Penelitian } & Probabilitas (Sig) & Keterangan \\
\hline 1. & $\begin{array}{l}\text { Ketersediaan Fasilitas Belajar Saat } \\
\text { Pembelajaran Daring }\end{array}$ & 0,200 & Normal \\
\hline 2. & Prestasi Belajar & 0,670 & Normal \\
\hline
\end{tabular}


Persyaratan uji normalitas adalah jika nilai signifikansi lebih besar dari $0,05(>0,05)$ maka data dapat dikatakan berdistribusi normal. Berdasarkan pengujian normalitas menggunakan metode Kolmogorof-Smirnov dengan bantuan aplikasi IBM SPSS Statistik v.25 diperoleh nilai signifikansi 0,200 untuk variabel ketersediaan fasilitas belajar saat pembelajaran daring dan nilai signifikansi 0,670 untuk variabel prestasi belajar peserta didik. Nilai signifikansi kedua variabel tersebut memenuhi asumsi normal yakni lebih besar dari $0,05(0,200>0,05$ dan $0,670>0,05)$, maka dapat disimpulkan data yang diperoleh tersebar dalam distribusi normal pada taraf signifikansi 0,05.

\section{Uji Linieritas Data}

Hasil uji linieritas dengan aplikasi IBM SPSS Statistik v.25 diperoleh nilai signifikansi $0,000<0,05$, hal ini menunjukkan bahwa data linier. Hasil uji linieritas dapat diperoleh rangkuman yang dapai dilihat padaTabel 2 .

Tabel 2. Rangkuman Hasil Uji Linieritas Data

\begin{tabular}{ccccc}
\hline No & \multicolumn{1}{c}{ Variabel Penelitian } & $\begin{array}{c}\text { Sig. } \\
\text { Linieirty }\end{array}$ & Signifikansi & Keterangan \\
\hline $\begin{array}{l}\text { Ketersediaan Fasilitas Belajar Saat } \\
\text { 1. }\end{array}$ & $\begin{array}{l}\text { Pembelajaran Daring dan Prestasi } \\
\text { Belajar }\end{array}$ & 0,000 & 0,05 & Linier \\
\hline
\end{tabular}

\section{B. Analisis Data}

\section{Mencari Persamaan Garis Regresi Linier}

Analisis data yang digunakan untuk pengujian hipotesis dalam penelitian ini adalah regresi linier. Rangkaian hasil regresi yang dilakukan dapat dilihat pada tabel berikut:

Tabel 3. Ringkasan Hasil Uji Regresi

\begin{tabular}{cccc}
\hline Variabel & $\begin{array}{c}\text { Koefisien Regresi } \\
\text { (b) }\end{array}$ & t & Sig \\
\cline { 1 - 2 } $\begin{array}{c}\text { Ketersediaan Fasilitas Belajar Saat } \\
\text { Pembelajaran Daring }\end{array}$ & 0,294 & \multirow{2}{*}{3,638} & \multirow{2}{*}{0,001} \\
\cline { 1 - 2 } Konstanta & & & \\
\hline R2 & 64,955 & & \\
\hline F & 0,159 & & \\
\hline Sig & 13,235 & \\
\hline
\end{tabular}

Besarnya harga koefisien ketersediaan fasilitas belajar saat pembelajaran daring $(X)$ sebesar 0,294 dan bilangan konstanta sebesar 64,955.

Berdasarkan angka-angka tersebut, maka dapat disusun persamaan sebagai berikut: $Y=0,294 X+64,955$

Persamaan tersebut menunjukkan bahwa nilai koefisien $X$ sebesar 0,294 artinya apabila nilai ketersediaan fasilitas belajar saat pembelajaran daring $(X)$ meningkat 1 poin maka nilai prestasi belajar (Y) akan meningkat 0,294. 


\section{Uji Korelasi}

Pengujian uji korelasi menggunakan uji korelasi product moment dengan menggunakan aplikasi IBM SPSS Statistik v.25, maka dapat dilihat hasilnya adalah sebagai berikut:

Tabel 4. Ringkasan Hasil Uji Korelasi

\begin{tabular}{|c|c|c|c|}
\hline \multicolumn{4}{|c|}{ Correlations } \\
\hline & & $\begin{array}{c}\text { Ketersediaan } \\
\text { Fasilitas Belajar }\end{array}$ & Prestasi Belajar \\
\hline \multirow{3}{*}{$\begin{array}{l}\text { Ketersediaan Fasilitas } \\
\text { Belajar }\end{array}$} & Pearson Correlation & 1 & $.399^{* *}$ \\
\hline & Sig. (2-tailed) & & 0,001 \\
\hline & $\mathrm{N}$ & 72 & 72 \\
\hline \multirow[t]{3}{*}{ Prestasi Belajar } & Pearson Correlation & $.399^{* *}$ & 1 \\
\hline & Sig. (2-tailed) & 0,001 & \\
\hline & $\mathrm{N}$ & 72 & 72 \\
\hline
\end{tabular}

${ }^{* *}$. Correlation is significant at the 0.01 level (2-tailed).

Berdasarkan tabel di atas dapat dilihat bahwa besar hubungan antara variabel ketersediaan fasilitas belajar saat pembelajaran daring dengan prestasi belajar adalah 0,399 hal ini menunjukkan adanya hubungan atau korelasi yang positif. Hubungan antara dua variabel tersebut tergolong rendah, seperti yang dikemukakan oleh Arikunto (2013) bahwa besarnya $r$ Product Moment tersebut terdapat pada rentang 0,200-0,399 dengan interpretasi antara variabel $\mathrm{X}$ dan $\mathrm{Y}$ terdapat korelasi yang rendah.

\section{Uji t}

Uji t merupakan pengujian untuk menunjukkan pengaruh variabel bebas yang ada dalam model terhadap variabel terikat. Hal ini dimaksudkan untuk mengetahui seberapa jauh pengaruh variabel bebas dalam menjelaskan variabel terikat. Untuk menunjukkan pengaruh variabel bebas terhadap variabel terikat.

Berdasarkan hasil perhitungan pengaruh ketersediaan fasilitas belajar saat pembelajaran daring terhadap prestasi belajar diperoleh nilai koefisien regresi 0,294 Pada taraf signifikansi $5 \%$ dapat diketahui thitung sebesar 3,638 dengan nilai signifikansi sebesar 0,001 karena koefisien regresi mempunyai nilai positif dan nilai signifikansi $(p)<0,05$ maka hipotesis yang berbunyi "Terdapat pengaruh yang signifikan antara ketersediaan fasilitas belajar saat pembelajaran daring terhadap prestasi belajar peserta didik SMK Karsa Mulya Palangka Raya pada tahun pelajaran 2021/2022" diterima.

\section{PEMBAHASAN}

Berdasarkan deskripsi data penelitian dapat diketahui bahwa terdapat pengaruh yang signifikan antara ketersediaan fasilitas belajar saat pembelajaran daring terhadap prestasi belajar peserta didik SMK Karsa Mulya Palangka Raya pada tahun pelajaran 2021/2022. Berdasarkan hasil perhitungan ketersediaan fasilitas belajar saat pembelajaran daring terhadap prestasi belajar peserta didik SMK Karsa Mulya Palangka Raya pada tahun pelajaran 2021/2022 diperoleh nilai koefisien regresi (b) sebesar 0,294. Pada taraf signifikansi $5 \%$ dapat diketahui thitung sebesar 3,638 dengan nilai signifikansi sebesar 0,001 karena koefisien regresi mempunyai nilai positif dan nilai signifikansi $(p)<0,05$ maka dapat 
disimpulkan, semakin lengkap ketersediaan fasilitas belajar saat pembelajaran daring maka semakin tinggi prestasi belajar peserta didik SMK Karsa Mulya Palangka Raya pada tahun pelajaran 2021/2022.

Hasil penelitian ini juga didukung oleh pendapat Arikunto (2014) bahwa lengkap dan tidaknya peralatan belajar, baik yang dimiliki peserta didik itu sendiri maupun yang dimiliki sekolah, dapat menimbulkan hasil akibat tertentu terhadap hasil belajar peserta didik, kekurangan peralatan belajar dapat membawa akibat yang negatif; antara lain misalnya peserta didik tidak bisa belajar secara baik, sehingga sulitlah diharapkan untuk mencapai prestasi yang tinggi. Sebab belajar tidak dapat dilakukan tanpa adanya sarana belajar yang cukup, semakin lengkap sarana belajar semakin dapat seorang peserta didik belajar dengan tidak terganggu.

\section{SIMPULAN DAN SARAN}

Berdasarkan data yang diperoleh dari hasil analisis yang dilakukan maka dapat ditarik kesimpulan bahwa terdapat pengaruh yang signifikan antara ketersediaan fasilitas belajar saat pembelajaran daring terhadap prestasi belajar peserta didik SMK Karsa Mulya Palangka Raya pada tahun pelajaran 2021/2022. Hal tersebut dapat ditunjukkan dengan nilai thitung sebesar 3,638, koefisien regresi (b) sebesar 0,294, dan nilai signifikansi sebesar 0,001 karena koefisien regresi mempunyai nilai positif dan nilai signifikan $(p)<0,05$ maka dapat disimpulkan bahwa semakin lengkap ketersediaan fasilitas belajar saat pembelajaran daring maka semakin tinggi prestasi belajar peserta didik SMK Karsa Mulya Palangka Raya pada tahun pelajaran 2021/2022.

Saran yang dapat diberikan adalah untuk menciptakan proses pembelajaran yang lebih optimal, maka orang tua dan guru diharapkan dapat mengontrol dan memotivasi peserta didik untuk belajar terutama mengikuti pembelajaran daring di masa pandemi Covid 19 dengan menyiapkan fasilitas belajar yang diperlukan peserta didik di rumah.

\section{DAFTAR PUSTAKA}

[1] Anitah, S. 2014. Media Pembelajaran. Surakarta: Panitia Sertifikasi Guru Rayon.

[2] Arikunto, S. 2013. Prosedur Penelitian Suatu Pendekatan Praktik. Jakarta: Rineka Cipta.

[3] Arikunto, S. 2014. Pengelolaan Kelas dan Peserta didik. Jakarta: Rajawali

[4] Dalyono, M. 2012. Psikologi Pendidikan. Semarang. IKIP Semarang Press.

[5] Djamarah, S. B. 2012. Psikologi Belajar. Jakarta: Rineka Cipta.

[6] Nashar. 2012. Peranan Motivasi dan Kemampuan awal dalam kegiatan Pembelajaran. Jakarta: Delia Press.

[7] Tim KBBI. 2016. Kamus Bebas Bahasa Indonesia. Jakrta: Balai Pustaka.

[8] Wiktionary. 2017. Ketersediaan. Diakses pada tanggal 18 November 2021 dari https://id.wiktionary.org/wiki/ketersediaan. 